\title{
Client Satisfaction with Prevention of Mother to Child Transmission of HIV Services in Public Hospitals of Hadiya Zone, Southern Ethiopia
}

\author{
Bahailu Balcha *1 Desta erkalo ${ }^{2} \quad$ Tilahun Beyene $^{3}$ \\ 1.Wolaita Sodo University, College of Medicine and Health Sciences, School of Public Health, Sodo, Ethiopia \\ 2.Haramaya university, College of Medicine and Health sciences, School of public Health, Harer, Ethiopia \\ 3.Wolaita Sodo University, College of Medicine and Health Sciences, School of Public Health, Sodo, Ethiopia
}

\begin{abstract}
Background: Prevention of mother-to-child transmission is a term used to describe a comprehensive package of services intended to reduce the risk of mother-to-child transmission of HIV. The vertical virus transmission from mother to child accounts for more than $90 \%$ of pediatric Acquired Immunodeficiency Syndrome. Published studies on the client satisfaction with PMTCT services' provision in Ethiopia are generally limited. Even fewer studies do examine client satisfaction with the PMTCT services. Therefore, this study is aimed to assess the client satisfaction with Prevention of Mother-to-Child Transmission of HIV services in public hospitals of Hadiya zone, southern Ethiopia 2017.

Methods: Institution based cross-sectional study design using quantitative data collection method was conducted in public hospitals from March 01 to April 10, 2017. A total of 423 pregnant women were consecutively interviewed until the required sample was obtained. The data was entered in to Epi-data and analyzed using SPSS. Bivariate and multivariable logistic regression analyses were computed to see the predictors for satisfaction of clients on PMTCT service.

Result: About $89.8 \%$ clients were satisfied with PMTCT services provided at public hospitals. The client satisfaction with PMTCT services was associated with waiting time $[\mathrm{AOR}=4.648,95 \% \mathrm{CI}=(2.183,9.897)]$, counseling time $[\mathrm{AOR}=3.748,95 \% \mathrm{CI}=(1.645,8.537)]$ and counseling given by same counselor before and after HIV test $[$ AOR $=0.193,95 \%$ CI: $(0.090,0.412)]$.
\end{abstract}

Conclusion: Clients' satisfaction by PMTCT service is very high.

Keywords: HIV, prevention, women, PMTCT.

DOI: $10.7176 / \mathrm{JHMN} / 89-02$

Publication date:May $31^{\text {st }} 2021$

\section{Introduction}

Human immunodeficiency virus has devastated Africa. Over 25 million or $69 \%$ of global HIV cases are in Africa(1). Of the 3.2 million children living with HIV in 2014, 91\% live in sub-Saharan Africa and $85 \%$ of HIVpositive pregnant women also live in the region (2).

Mother-to-child transmission (MTCT) of human immunodeficiency virus (HIV) entails transmission of HIV from an infected mother to her child. Also called "vertical" or "perinatal" transmission, MTCT can occur during pregnancy, labor, delivery, and breastfeeding (1). Over $90 \%$ of pediatric AIDS cases are from MTCT(4). PMTCT has four components: 1) primary prevention of HIV infection, 2) prevention of unintended pregnancies among HIV-positive women, 3) prevention of HIV transmission from women infected to their infants through treatment and care and 4) support to women infected with HIV, their infants and their families(4).

From the time when the program introduced, tremendous achievements observed globally particularly in access to service. Accordingly, an estimated 966000 women, or about two thirds $(67 \%)$ of the pregnant women living with HIV in low- and middle-income countries, received at least some effective ARV drugs in 2013 (2).

Vertical virus transmission from mother-to-child accounts for more than $90 \%$ of pediatric AIDS. Due to poor quality PMTCT services, it is estimated that over $90 \%$ of childhood HIV infections result from the transmission of the virus from mothers to their children during and soon after birth (4).

Coverage of anti-retroviral (ARV) medicines among HIV-positive pregnant women in Africa is roughly $80 \%$, which higher than many regions of the world(6), although in high-burden countries, such as Angola, Chad and Nigeria, less than half of pregnant or breastfeeding women living with HIV are receive ARV medicines (5).

In 2013 there were an estimated 793,700 people living with HIV including 200,300 children in Ethiopia. There were approximately 45,200 AIDS related deaths in 2013 and about 898,400 AIDS orphans in the same year. HIV adult prevalence is estimated at $1.5 \%$ in 2011 . However prevalence varies according to age, sex, gender and geographical location (10). The 2016 Ethiopian Demographic and Health Survey (EDHS) shows that $62 \%$ of pregnant women in the country had at least one ANC visit (17).

Few published studies are available on PMTCT services' provision in Ethiopia and even fewer examine client satisfaction with PMTCT services. Therefore, this study aims to contribute to science by assessing client 
satisfaction with PMTCT services provision at public hospitals of Hadiya Zone, southern Ethiopia

\section{Methods}

The study was an institution-based cross-sectional study conducted at three public hospitals in Hadiya Zone, approximately 200 kilometers southwest of Ethiopia's capital city, Addis Ababa. The study used quantitative data collection method from March 1 to April 10, 2017.

All public hospitals providing PMTCT services in Hadiya Zone, including Shone, Homecho, and Nigist Elleni Mohammed Memorial Teaching Hospitals, were included in our study. Sample size was determined using single population proportion formula at a $95 \%$ confidence level, $80 \%$ power of the test and $5 \%$ margin of error, where $p$, the proportion of clients satisfied with PMTCT services, was assumed to be $50 \%$. Considering $10 \%$ of non-response rate, the final sample size was 423 .

Sample was allocated proportionally to selected hospitals based on average ANC attendance in the threemonths preceding the study period. All sampled pregnant women who met inclusion criteria at ANC clinics were interviewed by diploma-level nurses using a structured questionnaire adapted from UNAIDS and Family Health International (FHI) $(8,9)$. The questionnaire was prepared in English, translated to Hadiyisa, and back-translated to English separately by two individuals to ensure consistency. Nurse data collectors were supervised by two BSc supervisors. All data collectors were selected from outside of study area to minimize bias. Incomplete and unclear questionnaires were returned to interviewers to be completed.

Data was entered, cleaned and analyzed using SPSS 20 and was cleaned by running frequencies, crosstabulation and sorting cases. Bivariate and multivariate logistic regression analyses were used to determine the association of independent variables with the dependent variable. Variables with $\mathrm{p}<0.25$ in bivariate analysis were entered into a multivariate logistic regression model. Odds ratio with $95 \%$ confidence were computed to identify the presence and strength of associations, and statistical significance was declared if $p<0.05$ was found. Final model was checked using the Hosmer-Lemeshow goodness of fit test. Cofounders, interaction and multicollinearity were checked to minimize bias.

Study protocol was approved by the Institutional Research Review Board of Jimma University's, Institute of Health Science and Community Services Ethical Review Committee. Permission was obtained from Hadiya Zone Health Department and participating hospitals. Informed verbal consent was obtained from participants prior to enrollment in the study. Participation in the study was voluntary and participants were informed of the right to withdraw from the study. Data collection was conducted confidentially and data was de-identified, delinked and stored in a secure location.

\section{Results}

A total of 423 women were interviewed, giving a response rate of $100 \%$. Age of respondents ranged from 16 to 43 with a mean age of $27.24( \pm 5.67)$ years. Only seventy-nine $(18.7 \%)$ women were unable to read and write. Three hundred nineteen (75.4\%) lived in urban areas and $219(51.8 \%)$ were housewives, followed by government employee 67(15.8\%). Three-fourths (75.4\%) belonged to the Hadiya ethnic group and 413 (97.6\%) were married (Table 1).

Table 1:-Socio-demographic characteristics of respondents, client satisfaction with PMTCT services in public hospitals of Hadiya zone, South Ethiopia, 2017.

\begin{tabular}{|llll|}
\hline Variables & Characteristics & Frequency & Percent \\
\cline { 2 - 4 } & $15-24$ & 131 & 31 \\
\cline { 2 - 4 } & $25-34$ & 236 & 55.8 \\
\cline { 2 - 4 } Marital status & $35-49$ & 56 & 13.2 \\
\cline { 2 - 4 } & Currently Married & 413 & 97.6 \\
\cline { 2 - 4 } Level education & Not married & 10 & 2.4 \\
\cline { 2 - 4 } & Unable to read and write & 79 & 18.7 \\
\cline { 2 - 4 } & Primary school & 190 & 34.9 \\
\cline { 2 - 4 } Ethnicity & Secondary school and above & 154 & 36.4 \\
& Hadiya & 319 & 75.4 \\
\cline { 2 - 4 } & Gurage & 40 & 2.5 \\
\cline { 2 - 4 } & Wolayita & 43 & 2.6 \\
\cline { 2 - 4 } & Amhara & 11 & 2.2 \\
\cline { 2 - 4 } & Others* & & \\
\hline
\end{tabular}




\begin{tabular}{|c|c|c|c|}
\hline Variables & Characteristics & Frequency & Percent \\
\hline \multirow[t]{4}{*}{ Religion } & Protestant & 290 & 68.6 \\
\hline & Orthodox & 87 & 20.6 \\
\hline & Muslim & 32 & 7.6 \\
\hline & Others** & 14 & 3.2 \\
\hline \multirow{5}{*}{$\begin{array}{l}\text { Occupational } \\
\text { status }\end{array}$} & Housewife & 219 & 51.8 \\
\hline & Government Employee & 67 & 15.8 \\
\hline & Student & 43 & 10.2 \\
\hline & Merchant & 79 & 18.7 \\
\hline & Others $* * *$ & 15 & 3.5 \\
\hline \multirow{2}{*}{$\begin{array}{ll}\text { Place } & \text { of } \\
\text { residence } & \\
\end{array}$} & Urban & 319 & 75.4 \\
\hline & Rural & 104 & 24.6 \\
\hline
\end{tabular}

Others*: silte, kembata, others**: catholic, Adventist seventh day,others ***: daily labourer, farmers

Most (79.7\%) women knew about the availability of PMTCT services before coming to ANC and most (234, 69.4\%) derived this information from health workers or health extension workers $(65,19.3 \%)$. Three hundred nineteen (75.4\%), women waited less than 30 minutes to see a provider. Mean duration of counseling session was 17.37 minutes. The same counselor provided pre- and post-test counseling for 337(79.9\%) women. Fifty-one (12.1\%) women expressed that a language barrier was present (Table 2).

Table 2:-Waiting time, duration, information source and perceived benefit of counseling session; client satisfaction with PMTCT services in public hospitals of Hadiya zone south Ethiopia, 2017.

\begin{tabular}{|c|c|c|c|}
\hline Variables & Characteristics & Frequency & Percent \\
\hline \multirow{2}{*}{$\begin{array}{l}\text { Awareness about the presence of PMTCT } \\
\text { before she came }\end{array}$} & Yes & 337 & 79.7 \\
\hline & No & 86 & 20.3 \\
\hline \multirow[t]{5}{*}{ Source of information of PMTCT } & Health workers & 234 & 69.4 \\
\hline & Mass media & 19 & 5.6 \\
\hline & Friends & 5 & 1.5 \\
\hline & Health extension workers & 65 & 19.3 \\
\hline & Others & 14 & 4.2 \\
\hline \multirow{2}{*}{$\begin{array}{l}\text { Pretest and posttest counseling was given by the } \\
\text { same counselor }\end{array}$} & Yes & 338 & 79.9 \\
\hline & No & 85 & 42.3 \\
\hline \multirow[t]{2}{*}{ There was no language barrier } & Yes & 372 & 87.9 \\
\hline & No & 51 & 12.1 \\
\hline \multirow[t]{2}{*}{ The counseling session was beneficial } & Yes & 413 & 97.6 \\
\hline & No & 10 & 2.4 \\
\hline \multirow{2}{*}{ Sex preference } & Yes & 113 & 26.7 \\
\hline & No & 310 & 73.3 \\
\hline \multirow[t]{2}{*}{ Waiting time to see a service provider } & $<30$ minutes & 319 & 75.4 \\
\hline & $>=30$ minutes & 104 & 24.6 \\
\hline \multirow[t]{2}{*}{ Counseling time } & $<=15$ minutes & 221 & 52.2 \\
\hline & $>15$ minutes & 202 & 47.8 \\
\hline \multirow[t]{2}{*}{ Reason for coming to the ANC center } & For antenatal care only & 244 & 57.7 \\
\hline & For antenatal care and to test for HIV & 179 & 42.3 \\
\hline \multirow[t]{2}{*}{ Would recommend the service to others } & Yes & 397 & 93.9 \\
\hline & No & 26 & 6.1 \\
\hline \multirow{2}{*}{$\begin{array}{l}\text { Are the opening hours of this clinic convenient } \\
\text { for you? }\end{array}$} & Yes & 376 & 88.9 \\
\hline & No & 47 & 11.1 \\
\hline \multirow{3}{*}{$\begin{array}{l}\text { How long did it take for you to arrive at this } \\
\text { clinic }\end{array}$} & $<30$ minutes & 264 & 62.4 \\
\hline & 30 min-1 hour & 124 & 29.3 \\
\hline & $>1$ hour & 35 & 8.3 \\
\hline
\end{tabular}

The majority of women were satisfied with PMTCT services. Most $(82.7 \%)$ women were "satisfied" or "very satisfied" with the comfort of the waiting room. Women were similarly satisfied with the counseling room and privacy during counseling, wait time and duration of the counseling session (Table 3). 
Table 3:-Client satisfaction with the comfort and privacy of counseling room, and adequacy of counseling session; client satisfaction with PMTCT services in public hospitals of Hadiya zone, south Ethiopia 2017.

\begin{tabular}{|c|c|c|c|c|c|c|c|c|c|c|}
\hline \multirow[t]{2}{*}{$\begin{array}{l}\text { Item: how do you rate your satisfaction } \\
\text { with: }\end{array}$} & \multicolumn{2}{|c|}{$\begin{array}{l}\text { Very } \\
\text { dissatisfied }\end{array}$} & \multicolumn{2}{|c|}{ Dissatisfied } & \multicolumn{2}{|c|}{ Neutral } & \multicolumn{2}{|c|}{ Satisfied } & \multicolumn{2}{|c|}{$\begin{array}{l}\text { Very } \\
\text { satisfied }\end{array}$} \\
\hline & No & $\%$ & No & $\%$ & No & $\%$ & No & $\%$ & No & $\%$ \\
\hline $\begin{array}{l}\text { Provider's greeting was good and } \\
\text { friendly? }\end{array}$ & 1 & 0.2 & 55 & 13 & 24 & 5.7 & 243 & 57.4 & 100 & 23.6 \\
\hline Comfort of the waiting room & 2 & 0.5 & 39 & 9.2 & 32 & 7.6 & 259 & 61.2 & 91 & 21.5 \\
\hline Waiting time & 5 & 1.2 & 52 & 12.3 & 26 & 6.1 & 265 & 62.6 & 76 & 18 \\
\hline Comfort of the counseling room & 4 & 0.9 & 44 & 10.4 & 28 & 6.6 & 258 & 61 & 84 & 19.9 \\
\hline $\begin{array}{l}\text { Adequacy of duration of the } \\
\text { counseling session }\end{array}$ & 4 & 0.9 & 44 & 10.4 & 30 & 7.1 & 254 & 60 & 91 & 21.5 \\
\hline Privacy of the counseling room & 4 & 0.9 & 44 & 10.4 & 28 & 6.6 & 255 & 60.3 & 92 & 21.7 \\
\hline $\begin{array}{l}\text { The cleanliness and sanitation of } \\
\text { procedure }\end{array}$ & 7 & 1.7 & 53 & 12.5 & 27 & 6.4 & 251 & 59.3 & 85 & 20.1 \\
\hline
\end{tabular}

Most women were also satisfied with the counselors themselves, believing them to be respectful, trustworthy, and competent. Three hundred seventy-one $(87.7 \%)$ women were "satisfied" or "very satisfied" with the service (Table 4).

Table 4:- Client satisfaction by counselor's characteristics and availability of services, client satisfaction with PMTCT services in public hospitals of Hadiya zone south Ethiopia, 2017.

\begin{tabular}{|l|l|l|l|l|l|l|l|l|l|l|l|}
\hline \multirow{2}{*}{$\begin{array}{l}\text { Item: how do you rate your satisfaction } \\
\text { with: }\end{array}$} & \multicolumn{2}{l|}{$\begin{array}{l}\text { Very } \\
\text { dissatisfied }\end{array}$} & \multicolumn{2}{l}{ Dissatisfied } & \multicolumn{2}{l|}{ neutral } & \multicolumn{2}{l|}{ Satisfied } & \multicolumn{2}{l}{$\begin{array}{l}\text { Very } \\
\text { satisfied }\end{array}$} \\
\cline { 2 - 14 } & No & $\%$ & No & $\%$ & No & $\%$ & No & $\%$ & No & $\%$ \\
\hline Respectfulness of the counselor & 2 & 0.5 & 55 & 13 & 30 & 7.1 & 237 & 56 & 99 & 23.4 \\
\hline Trustworthiness of the counselor & 5 & 1.2 & 57 & 13.5 & 24 & 5.7 & 237 & 56 & 100 & 23.6 \\
\hline Clarity of the counselor's explanation & 3 & 0.7 & 45 & 10.6 & 33 & 7.8 & 246 & 57 & 101 & 23.9 \\
\hline The counselor's competency & 4 & 0.9 & 55 & 13 & 21 & 5 & 239 & 56.5 & 104 & 24.6 \\
\hline $\begin{array}{l}\text { laboratory service available when } \\
\text { always needed }\end{array}$ & 5 & 1.2 & 56 & 13.2 & 22 & 5.2 & 245 & 57.9 & 95 & 22.5 \\
\hline $\begin{array}{l}\text { availability of information to MTCT } \\
\text { and PMTCT }\end{array}$ & 5 & 1.2 & 52 & 12.3 & 16 & 3.8 & 249 & 58.9 & 101 & 23.9 \\
\hline $\begin{array}{l}\text { Clear explanation about } \\
\text { Appointment date }\end{array}$ & 3 & 0.7 & 51 & 12.1 & 21 & 5 & 245 & 57.9 & 95 & 22.5 \\
\hline The overall services & 5 & 1.2 & 37 & 8.7 & 10 & 2.4 & 271 & 64.1 & 100 & 23.6 \\
\hline
\end{tabular}

Women who waited less than 30 minutes to see a provider had odds 4.6 times higher $[\mathrm{AOR}=4.65,95 \% \mathrm{CI}=$ $(2.18,9.89)$ of being satisfied as compared to those that waited $>=30$ minutes $[\mathrm{AOR}=4.65,95 \% \mathrm{CI}=$ $(2.18,9.89)$, p-value $\leq 0.00]$. Women counseled for more than 15 minutes had odds 3.7 times more likely to be satisfied than women counseled for $\leq 15$ minutes (AOR $=3.7,95 \% \mathrm{CI} ; 1.65,8.54)$. Women who were not counseled by the same ANC counselor before and after HIV test were considerably less likely to be satisfied as compared to women whose counseling given by same counselor (AOR $=0.19,95 \%$ CI; 0.09, 0.41) (Table 5).

Table 5:- Multivariable logistic regression analysis of variables predicting satisfaction of PMTCT clients in public hospitals of Hadiya zone, south Ethiopia 2017.

\begin{tabular}{|c|c|c|c|c|c|c|}
\hline \multicolumn{2}{|l|}{ Variable } & Satisfied & Dissatisfied & & AOR & $95 \%$ CI of \\
\hline Name & Category & No $(\%)$ & No $(\%)$ & value & & AOR \\
\hline $\begin{array}{l}\text { counseling given by the same } \\
\text { counselor in pretest information and } \\
\text { posttest counseling }\end{array}$ & $\begin{array}{l}\text { Yes } \\
\text { No }\end{array}$ & $\begin{array}{l}317(93.8) \\
63(71.4)\end{array}$ & $\begin{array}{l}21(6.2) \\
22(28.6)\end{array}$ & $\begin{array}{l}1 \\
0.000\end{array}$ & 0.19 & $(0.09,0.41)$ \\
\hline Waiting time & $\begin{array}{l}<30 \text { minutes } \\
>=30 \text { minutes }\end{array}$ & $\begin{array}{l}299(93.7) \\
81(77.9)\end{array}$ & $\begin{array}{l}20(6.3) \\
23(22.1)\end{array}$ & $\begin{array}{l}0.000 \\
1\end{array}$ & 4.65 & $(2.18,9.89)$ \\
\hline Counseling time(pre and posttest) & $\begin{array}{l}<= \\
\text { minutes } \\
<15 \text { minutes }\end{array}$ & $\begin{array}{l}188(85.1) \\
192(95)\end{array}$ & $\begin{array}{l}33(14.9) \\
10(5)\end{array}$ & $\begin{array}{l}1 \\
0.002\end{array}$ & 3.75 & $(1.65,8.54)$ \\
\hline
\end{tabular}

Note: Hosmer and Lemeshow Test $=0.885$ therefore the model adequately fits the data

\section{Discussion}

Almost $80 \%$ of women were satisfied with the privacy of counseling rooms, which is similar to a study in Addis Ababa(12) and slightly higher than a study in Tanzania (11). Overall satisfaction with PMTCT service was 89.8\%, which is similar to Kafa Zone(6) and Dessie City Administration(16) and higher than studies in Nigeria, 
Adama [Ethiopia] and Tanzania (range 40\% - 75\%) (13,7,11).

Not being counseled by the same ANC counselor pre- and post-test was a significant predictor of client satisfaction, which is consistent with the study in Adama (7). It is recommended that the same person offer preand post-test counseling (7). These findings might be related to clients' concerns regarding issues of confidentiality. [Extended counseling sessions were also tied to patient satisfaction in our study. The odds of a woman being satisfied were 3.7 times higher among women whose counseling sessions lasted more than 15 minutes, a finding supported by the study in Addis Ababa (12). Discussing for extended periods may decrease women's fears about a positive test result. Lastly, women who waited less than 30 minutes to see counselor had higher odds of being to be satisfied, which is consistent with a study in Zimbabwe (15). Decreasing wait time might encourage service utilization.

Our study has several strengths, including employing a validated and standardized questionnaire that was tested and revised. Our study also used newly implemented Federal Ministry of Health (FMOH) guidelines on PMTCT to avoid measurement bias. Since respondents were interviewed in the hospital setting, they may have given responses biased in favor of the providers/healthcare facility; however, interviews were conducted in a separate room by non-staff members to minimize bias

In general in all public hospitals of Hadiya zone health care provider should improve provider-client communication and devising ways of increasing clients' satisfaction with PMTCT services particularly in respecting the clients and developing Trustworthiness. Since current waiting time of clients to see the counselor is encouraging, providers should maintain such working culture in this regard

\section{Acknowledgments}

Our gratitude goes to supervisors, data collectors, study respondents and Hadiya Zone Health Department for facilitating the study.

\section{Authors' contributions}

Behailu Balcha: had made substantial contributions to conception and design, acquisition of data, analysis and interpretation of data, and Desta Erkalo had revised the paper critically for important intellectual content starting from proposal development to manuscript preparation. All authors read and approved the final manuscript.

\section{Competing interests}

The authors declare that they have no competing interests.

\section{Funding statement}

We would like to thank Jimma University's, Institute of Health for funding this research

\section{References}

1. FMOH/Ethiopia. National Comprehensive PMTCT Training Participant's Manual, April 2016

2. WHO.HIV REPORTING: Global Update on the Health Sector Response to HIV, 2014, 1-168.

3. UNAIDS. REGIONAL FACT SHEET, 2012

4. FHAPCO/FMOH: Guideline for Prevention of Mother to Child Transmission, 2011, Ethiopia; p1-51

5. Anthonia A. Assessing and Assuring Quality of Health Care in Africa. African Journal of Medical Sciences. 2010; 3(1): $31-6$

6. Bayou NB, Tsehay Y E. Quality of PMTCT Services in Gebretsadiq Shawo Memorial Hospital, Kafa Zone, Southwest Ethiopia: A Descriptive Study. Open Access Library Journal, 2012; (2) : e1499

7. Asefa A and Mitike G. Prevention of Mother-to-Child Transmission (PMTCT) of HIV services in Adama town, Ethiopia: clients' satisfaction and challenges experienced by service providers. BMC Pregnancy and Childbirth, 2014; 14:57.

8. UNAIDS. Tools for evaluating HIV voluntary counseling. Geneva, Switzerland; 2000.

9. FHI. Baseline Assessment Tools For Prevention Of Mother To Child Transimission (PMTCT) Of Hiv.2003.P 1-92

10. FHAPCO. Country progress report on the HIV response. Addis Ababa, Ethiopia; 2014 p. 1-51

11. Lyatuu MB, Msamanga GI and Kalinga AK. Clients' Satisfaction with Services for Prevention of MotherTo-Child Transmission of HIV in Dodoma Rural District. East African Journal of Public Health , 2008 ; $5: 3$

12. Ismail H, Ali A. Pregnant women's satisfaction and comprehension level of information given during HIV Counseling and Testing for PMTCT in public health facilities in Addis Ababa,2008

13. Ashipa, T, Ofili, A.N., Ighedosa, S.U. Assessment Of Clients' Satisfaction With The Pmtct Counselling Service In Benin City, Edo State, Nigeria. Jmbr: A Peer-Review Journal Of Biomedical Sciences;2013;12(2): 150-165

14. CDC: Testing and Counseling for Prevention of Mother-to-Child Transmission of HIV (TC for PMTCT). 
Centers for Disease Control and Prevention, Reference Guide. Atlanta: Atlanta: Center for Disease Control; 2006

15. B. R Mutede, E Tachiwenyika, R. Musarandega, B Khabo, M Mhangara, E. Tumbare 2014. What factors are critical in improving client satisfaction with PMTCT services in Zimbabwe;Findings from a client satisfaction survey b.3cdn.net/glaser/7ac56e629d805de3b4_qjm6i68bc.pdf

16. Abaynew Y. Quality of Prevention of Mother to Child Transmission (PMTCT) Services in Dessie Referral Hospital, Dessie City Administration, Ethiopia: Client Perspective. Neonat Pediatr Med ;2016;3:1

17. EDHS 2016. Central Statistical Agency (CSA) [Ethiopia] and ICF. 2016. Ethiopia Demographic and Health Survey 2016. Addis Ababa, Ethiopia, and Rockville, Maryland, USA: CSA and ICF. 